\title{
Pengaruh Perbedaan Suhu Pemeliharaan terhadap Kualitas Fisik Daging Ayam Broiler Periode Finisher
}

\section{Effect of Different Breeding Temperatures on the Physical Quality of Meat of Broiler Chicken at Finisher Period}

\author{
S. R. Rini, Sugiharto dan L. D. Mahfudz \\ Departemen Peternakan, Fakultas Peternakan dan Pertanian, Universitas Diponegoro \\ Jln Prof. Soedarto, SH, Semarang (50275), Indonesia \\ Corresponding Author: rinis5225@gmail.com
}

\begin{abstract}
The aim of this research was to determine differences the physical quality (pH, drip loss, WHC and colour) of broiler chicken meat between two maintenance temperatures (comfortable temperature $\left(23-24^{\circ} \mathrm{C}\right.$ ) and high temperature $\left(35-36^{\circ} \mathrm{C}\right)$. The materials used in this study were 20 male broiler finisher period (age 21 days) with an average initial weight of $1.17 \mathrm{~g} \pm 0.03(\mathrm{CV}=2.94 \%)$, which 10 animals raised at a comfortable temperature $\left(23-24{ }^{\circ} \mathrm{C}\right)$ and the other 10 animals were raised in high temperatures (35-36). On day 35, broilers were stunned and sampled. Meat samples was taken from chest. Independent $t$ test was used in the experiment to see the difference in between.The results showed that the physical meat quality including at differentces maintance between broiler raised at a comfortable temperature $\left(23-24^{\circ} \mathrm{C}\right)$ and broiler were raised in high temperatures (35$\left.36{ }^{\circ} \mathrm{C}\right)$ was significantly different effect $(\mathrm{P}<0.05)$ on $\mathrm{pH}$, drip loss, WHC and meat colour $\left(\mathrm{L}^{*}=\right.$ lightness and $\mathrm{a}^{*}=$ redness), but did not significantly effect $(\mathrm{P}>0.05)$ on yellowness $\left(\mathrm{b}^{*}\right)$ meat color. Conclution of this research was broiler chickens raised at high temperatures have lower physical quality than broiler chickens which are kept at a comfortable temperature.
\end{abstract}

Key words: male broiler, breeding temperature, physical quality meat

\begin{abstract}
ABSTRAK
Tujuan penelitian ini adalah untuk mengetahui perbedaan kualitas fisik ( $\mathrm{pH}$, drip loss, WHC dan warna) daging ayam broiler broiler antara dua suhu pemeliharaan (suhu nyaman $\left(23-24^{\circ} \mathrm{C}\right)$ dan suhu tinggi $\left(35-36^{\circ} \mathrm{C}\right)$. Materi yang digunakan dalam penelitian ini adalah 20 ekor ayam jantan periode finisher (umur 21 hari) dengan ratarata berat awal $1,17 \mathrm{~g} \pm 0,03(\mathrm{CV}=2,94 \%)$, dengan 10 ternak dibesarkan pada suhu yang nyaman $\left(23-24^{\circ} \mathrm{C}\right)$ dan 10 ternak lainnya dibesarkan dalam suhu tinggi $\left(35-36^{\circ} \mathrm{C}\right)$. Pada hari ke-35, ayam broiler disembelih dan diambil sampelnya. Sampel daging diambil dari dada. Uji t test independen digunakan dalam penelitian ini untuk dapat melihat perbedaan keduanya. Hasil penelitian menunjukkan bahwa kualitas fisik daging pada perbedaan pemeliharaan antara broiler yang dipelihara pada suhu yang nyaman $\left(23-24^{\circ} \mathrm{C}\right)$ dan broiler dipelihara pada suhu tinggi $\left(35-36^{\circ} \mathrm{C}\right)$ secara signifikan berbeda nyata $(\mathrm{P}<0,05)$ pada $\mathrm{pH}$, drip loss, WHC dan warna mat $(\mathrm{L} *=$ lightness dan $\mathrm{a} *=$ kemerahan), tetapi tidak berbeda nyata $(\mathrm{P}>0,05)$ pada warna kekuningan $(\mathrm{b} *)$ daging. Kesimpulan dari penelitian ini adalah ayam broiler yang dipelihara pada suhu tinggi memiliki kualitas fisik yang lebih rendah daripada ayam broiler yang dipelihara pada suhu yang nyaman.
\end{abstract}

Kata kunci: Ayam broiler jantan, suhu pemeliharaan, kualitas fisik daging.

\section{PENDAHULUAN}

Ayam Broiler merupakan hewan homeothermis yaitu hewan dengan suhu nyaman $24^{\circ} \mathrm{C}$, dimana akan berusaha mempertahankan suhu tubuhnya dalam keadaan relatif konstan dengan melalui peningkatan frekuensi pernafasan dan penurunan konsumsi pakan serta jumlah konsumsi air minum (Kusnadi, 2009). Ayam broiler merupakan ayam yang sangat rentan terhadap perubahan suhu lingkungan yang ekstrim. Ayam broiler memiliki suhu dan kelembaban optimal untuk menunjang pertumbuhan yaitu berkisar, $20-25^{\circ} \mathrm{C}$ dan 50 70\% (Sugito et al., 2011). Ayam broiler memiliki efisiensi dalam mengubah pakan menjadi daging yang baik serta pertumbuhannya cepat, ayam broiler juga mudah mengalami stres apabila suhu lingkungan tinggi (Setiaji dan Sudarman, 
2006). Daging ayam broiler merupakan bahan pangan sumber protein hewani yang bergizi tinggi, lezat, mudah ditemui dan memiliki harga yang relatif murah. Keadaan ini memicu peningkatan permintaan daging ayam dari tahun ke tahun. Tingkat konsumsi daging ayam pada tahun 2013 sampai dengan tahun 2017 menunjukkan bahwa rata-rata konsumsi per kapita per minggu masingmasing sebanyak $0,078 \mathrm{~kg} ; 0,086 \mathrm{~kg}, 0,111$ $\mathrm{kg}$ dan 0,124 kg (Badan Pusat Statistik, 2018).

Namun, seiring dengan peningkatan tingkat pendidikan dan pendapatan, masyarakat saat ini mulai selektif dalam memilih daging ayam broiler. Hanya daging broiler dengan kualitas baik yang akan di konsumsi masyarakat. Diantara parameter kualitas daging, kualitas fisik yang meliputi $\mathrm{pH}$, water holding capacity (WHC) atau daya ikat air, drip loss dan warna daging merupakan hal yang menjadi perhatian konsumen. Terdapat beberapa faktor yang berpengaruh terhadap kualitas fisik daging ayam broiler, dan suhu lingkungan pemeliharaan merupakan salah satunya. Beberapa literatur menunjukkan bahwa stres akibat suhu lingkungan yang tinggi sebelum ayam dipotong dapat menyebabkan penurunan kualitas daging ayam broiler karena ayam akan mengalami heat stres. Stres panas selama periode pertumbuhan broiler juga sering dikaitkan dengan karakteristik daging (Lucas dan Rostagno, 2013).Wang et al. (2017) menyatakan bahwa stres sebelum pemotongan dapat menyebabkan akumulasi asam laktat dan degradasi glikogen menjadi lebih cepat. Hal tersebut akan menimbulkan penurunan $\mathrm{pH}$ daging menjadi lebih cepat dan suasana daging menjadi lebih asam, dimana keasaman dalam daging tersebut dapat menimbulkan denaturasi protein daging. Ketika denaturasi protein terjadi, maka akan menyebabkan daging menjadi pale, soft, exudative (PSE) atau biasa disebut pucat, lembek dan berair. Suhu lingkungan yang tinggi selain menyebabkan penurunan $\mathrm{pH}$ yang sangat cepat juga akan menyebabkan water holding capacity (WHC) daging menjadi rendah dan kehilangan drip yang lebih besar (Lawrie, 2003).

Tujuan dari penelitian ini adalah untuk mengkaji pengaruh perbedaan suhu pemeliharaan terhadap kualitas fisik yang meliputi $\mathrm{pH}$, drip loss, water holding capacity (WHC) dan warna daging ayam broiler. Manfaat dari penelitian ini adalah dapat memberikan informasi tentang suhu pemeliharaan yang berbeda dan efeknya terhadap kualitas fisik daging ayam broiler. Hipotesis dari penelitian ini adalah ayam broiler yang dipelihara pada suhu yang tinggi memiliki kualitas fisik daging yang lebih rendah dibandingkan dengan kualitas fisik daging ayam broiler yang dipelihara pada suhu yang nyaman.

\section{MATERI DAN METODE}

Penelitian dilaksanakan pada $8-23$ Maret 2018. Pemeliharaan ayam dilakukan di Kandang Unggas Fakultas Peternakan dan Pertanian, Universitas Diponegoro, Semarang. Analisis $\mathrm{pH}$ dan drip loss dilakukan di Laboratorium Fisiologi dan Biokimia, Fakultas Peternakan dan Pertanian, Universitas Diponegoro, Semarang. Analisis WHC dilaksanakan di Laboratoium Ilmu Nutrisi dan Pakan. Analisis warna daging ayam broiler dilaksanakan di Laboratorium Terpadu Universitas Diponegoro, Semarang.

Materi yang digunakan pada penelitian ini adalah ayam broiler jantan periode finisher berumur 21 hari sebanyak 20 ekor yang memiliki bobot awal rata-rata 1,17 $\mathrm{g} \pm 0,03 \mathrm{~kg}(\mathrm{CV}=2,94 \%)$. Penelitian ini menggunakan 2 perlakuan suhu pemeliharaan dengan masing-masing perlakuan terdiri dari 10 ulangan. Perlakuan yang digunakan diantaranya: suhu pemeliharaan tinggi $35_{-} 36^{\circ} \mathrm{C}$ dan suhu pemeliharaan nyaman $23_{-} 24^{\circ} \mathrm{C}$. Pakan yang digunakan dalam penelitian ini adalah ransum komersil jenis Finisher S-12 yang diproduksi oleh PT. Charoen Pokphan Indonesia Tbk dengan kadar air 11, 20\%, kadar abu 6,86\%, kadar protei kasar 3,96\%, lemak kasar 4,19\% dan serat kasar 21,27\% (analisis laboratorium). Ruangan penelitian 
berukuran 1,35 x $1,35 \mathrm{~m}$. Ruangan $23-24{ }^{\circ} \mathrm{C}$ denagan air conditioner untuk pendingin kandang, ruangan $35-36^{\circ} \mathrm{C}$ menggunakan thermostat untuk pengatur suhu didalam kandang, heater yang terdiri dari 6 lampu bohlam 60 watt, lampu LED sebanyak 4 buah untuk penerangan dimalam hari, sirkulasi udara dengan blower exhause. Pakan diberikan pada pagi dan sore hari serta air minum diberikan secara ad libitum. Perlakuan dilakukan selama 12 jam dimulai dari jam 07.00 sampai dengan jam 19.00 WIB, kemudian setelahnya heater dan air conditioner dimatikan, namun lampu penerangan tetap menyala. Suhu dan kelembaban di kedua kandang dicatat pada pukul 07.00 pagi, 13.00 siang dan pukul 19.00 malam serta suhu dan kelembaban di lingkungan kandang.

Pengambilan data dilakukan pada akhir pemeliharaan ketika ayam berumur 35 hari (5 minggu). Pengambilan sampel untuk analisis kualitas fisik daging dilakukan dengan mengambil fillet pada bagian dada yaitu otot Pectoralis superficialis. Variabel kualitas fisik daging yang di analis yaitu $\mathrm{pH}$, drip loss, WHC dan warna daging.

Nilai $\mathrm{pH}$ daging yang diukur $\mathrm{pH}$ awal (45 menit) dan $\mathrm{pH}$ akhir (24 jam) setelah pemotongan. Pengukuran $\mathrm{pH}$ menggunakan digital $\mathrm{pH}$ meter merk Eco Testr dengan ketelitian $\pm 0,1$.

Pengujian drip loss dengan cara sampel daging yang akan digunakan ditimbang berat awal (X) nya., selanjutnya dimasukkan dalam plastik wrap dan dimasukkan ke dalam refrigerator selama 24 jam. Sampel ditimbang kembali untuk menentukan berak akhirnya (Y) dengan sebelumnya diseka dengan tisu tanpa ditekan. Drip loss dihitung dengan rumus:

$$
\text { Drip loss }=\frac{\mathrm{x}-\mathrm{y}}{\mathrm{x}} \times 100 \%
$$

Pengukuran water holding capacity (WHC) dilakukan berdasarkan metode Barbut (1993) yang diterapkan lee et al. (2015) dengan sedikit modifikasi. Pengujian dimulai dengan menghaluskan daging dada yang telah bersih dari kulit dan lemak sebanyak 2 gr, Menimbang wadah tube dan sampel daging yang telah dihaluskan, Memasukkan sampel daging tersebut ke dalam tube dan menambahkan Nacl 0,6 M sebanyak $4 \mathrm{ml}$. Campuran sampel dan $\mathrm{NaCl}$ divortex selama 30 detik dan diinkubasi selama 30 menit pada suhu $4^{\circ} \mathrm{C}$. Tahap berikutnya disentrifugasi (Sorvall RC-58 Refrigerated Super speed Centrifuge) pada $2889 \mathrm{rpm}$ selama 30 menit pada $4{ }^{\circ} \mathrm{C}$. Supernatan dibuang, dan endapan ditimbang. water holding capacity (WHC) dihitung dengan rumus:

$$
\begin{gathered}
\text { Water holding capacity }(\mathrm{WHC})= \\
\frac{4 \mathrm{ml} \text { - supernatan yang dibuang }(\mathrm{ml})}{4 \mathrm{ml}} \times 100 \%
\end{gathered}
$$

Pengukuran warna daging menggunakan alat chromatometer minolta colour reader yang terdiri dari: $\mathrm{L}^{*}$ (Kecerahan, $a^{*}$ dan $b^{*}$ (sistem warna CIELAB) pada permukaan posterior daging dada. Warna diukur pada tiga sisi berbeda.

Analisa statistik data yang digunakan adalah Uji t (t-test) dengan membandingkan perbedaan kualitas fisik ( $\mathrm{pH}$, drip loss, WHC dan warna daging) yang dipelihara pada suhu tinggi $35-36^{\circ} \mathrm{C}$ dan suhu nyaman $23-24^{\circ} \mathrm{C}$.

\section{HASIL DAN PEMBAHASAN}

Secara umum kualitas daging dapat dilihat dari paramater fisik daging. Sifat fisik daging yang diamati pada penelitian ini meliputi $\mathrm{pH}$, drip loss, water holding capacity (WHC) dan warna daging. Hasil analisis uji fisik daging ayam broiler periode finisher pada suhu pemeliharaan yang berbeda, ditampilkan pada Tabel 3 .

\section{pH Daging}

Hasil analisis $\mathrm{pH}$ daging ayam broiler dengan perlakuan suhu pemeliharaan yang berbeda dapat dilihat pada tabel 3, perhitungan analisis ragam terdapat pada lampiran 1 dan 2. Berdasarkan hasil uji t-test, $\mathrm{pH}$ daging ayam broiler pada kedua perlakuan adalah berbeda nyata $(\mathrm{P}<0,05)$. Rerata nilai $\mathrm{pH}$ daging dada ayam broiler yang dipelihara pada suhu yang tinggi (35$36^{\circ} \mathrm{C}$ menurun dengan cepat dari 5,87 pada 45 menit postmortem menjadi 5,48 pada 24 jam postmortem, sedangkan pada lingkungan 
pemeliharaan yang nyaman $\left(23-24^{\circ} \mathrm{C}\right)$ rerata $\mathrm{pH}$ awal (45 menit postmortem) sebesar 6,24 dengan $\mathrm{pH}$ akhir sebesar 5,83. Hasil penelitian ini sesuai dengan penelitian Fernandes et al. (2016) bahwa ayam broiler yang dipelihara dengan rata-rata suhu pemeliharaan $33^{\circ} \mathrm{C}$ dan kelembaban relatif $83 \%$ memiliki $\mathrm{pH}$ daging dada yang rendah yaitu sebesar 5,30.

Tabel 3. Rataan dan standar deviasi pengaruh perlakuan terhadap kualitas fisik daging ayam broiler

\begin{tabular}{lccc}
\hline \multirow{2}{*}{ Variabel } & \multicolumn{2}{c}{ Suhu pemeliharaan } & \multirow{2}{*}{ Uji t } \\
\cline { 2 - 3 } & $\mathrm{T} 1\left(35-36^{\circ} \mathrm{C}\right)$ & $\mathrm{T} 2\left(23-24^{\circ} \mathrm{C}\right)$ & \\
\hline pH 45 menit & $5,84 \pm 0,12$ & $6,12 \pm 0,15$ & $\mathrm{~s}$ \\
pH 24 jam & $5,48 \pm 0,10$ & $5,83 \pm 0,14$ & $\mathrm{~s}$ \\
Drip loss (\%) & $4,18 \pm 0,32$ & $2,62 \pm 0,42$ & $\mathrm{~s}$ \\
Water Holding Capacity (WHC) (\%) & $21,59 \pm 1,34$ & $25,45 \pm 0,89$ & $\mathrm{~s}$ \\
Warna daging & & & \\
$\mathrm{L}^{*}$ & $54,03 \pm 0,87$ & $50,30 \pm 1,25$ & $\mathrm{~s}$ \\
$\mathrm{a}^{*}$ & $7,70 \pm 0,40$ & $8,57 \pm 0,70$ & $\mathrm{~s}$ \\
$\mathrm{~b}^{*}$ & $13,43 \pm 0,61$ & $13,07 \pm 0,80$ & $\mathrm{~ns}$ \\
\hline
\end{tabular}

Ket. : berbeda nyata dengan taraf $5 \%$ pada superskrip yang berbeda, $\mathrm{ns}=$ nonsignifikan , $\mathrm{s}=$ signifikan.

Nilai pH pada suhu pemeliharaan nyaman masih tergolong normal, karena menurut Le Bihan-Duval et al. (2008) dalam Fernandes et al. (2016), nilai pH untuk daging ayam, khususnya daging dada, memiliki $\mathrm{pH}$ akhir (24 jam) postmortem antara 5,7 sampai 5,9. Namun, $\mathrm{pH}$ daging ayam broiler yang dipelihara pada suhu lingkungan yang tinggi berada dibawah standar $\mathrm{pH}$ daging. Nilai $\mathrm{pH}$ akhir yang rendah pada kelompok suhu pemeliharaan $35-36^{\circ}$ dikategorikan sebagai daging pale, soft, exudative (PSE). Hal ini sesuai dengan Fletcher (2002) dalam Nkukwana et al. (2015) yang melaporkan nilai rentang ambang $\mathrm{pH}$, dimana nilai $\mathrm{pH} \quad<5,7$ dikategorikan sebagai daging PSE, nilai 5,76,1 untuk kualitas standar, dan nilai > 6,1 untuk daging dark, firm, dry (DFD). Daging PSE ditandai dengan warna daging yang pucat (pale), lembek (soft) dan basah pada permukaan (exudative) (Song dan King, 2015).

$\mathrm{pH}$ sangat mempengaruhi kualitas daging, karena nilai $\mathrm{pH}$ adalah refleksi langsung dari kandungan asam otot, dan mempengaruhi keempukan, daya ikat air dan warna daging (Toplu et al., 2014). Pada penelitian ini perbedaan suhu pemeliharaan memberikan pengaruh nyata terhadap nilai
pH daging ayam broiler dimana pada pemeliharaan suhu lingkungan yang tinggi $\left(35-36^{\circ} \mathrm{C}\right)$ memiliki $\mathrm{pH}$ lebih rendah (asam). Perbedaan nilai $\mathrm{pH}$ dan tingkat penurunan $\mathrm{pH}$ antara kelompok suhu pemeliharaan 35$36^{\circ} \mathrm{C}$ dan $23-24^{\circ} \mathrm{C}$ dapat dikaitkan dengan konsentrasi asam laktat dalam jaringan otot yang berbeda setelah pemotongan. Ayam broiler yang dipelihara pada suhu lingkungan yang tinggi akan mengalami stres panas yang dapat meningkatkan pelepasan hormon, mempercepat penguraian glikogen otot oleh enzim-enzim glikolisis secara anaerob dan akumulasi asam laktat yang menyebabkan tingginya produksi asam laktat.

Asam laktat yang tinggi dalam daging akan mengakibatkan penurunan $\mathrm{pH}$ postmortem secara cepat dan $\mathrm{pH}$ akhir daging yang rendah. Hal ini didukung oleh pernyataan Zhang et al. (2012) bahwa $\mathrm{pH}$ akhir dada ayam yang mengalami stres panas $(5,72)$ menunjukkan $\mathrm{pH}$ akhir yang lebih rendah daripada yang berasal dari ayam yang dipelihara pada kondisi thermoneutral $(5,88)$. Hal tersebut merupakan akibat meningkatnya tingkat postmortem glikolisis karena aktivitas enzim glikolitik yang tinggi (kinase piruvat dan dehidrogenase laktat) dan lebih banyak piruvat yang diubah menjadi asam laktat 
daripada ayam pedaging yang dipelihara pada kondisi thermoneutral.

\section{Drip loss}

Hasil analisis drip loss daging ayam broiler dengan perlakuan suhu pemeliharaan yang berbeda dapat dilihat pada tabel 3. Hasil analisis statistik menunjukkan bahwa drip loss daging (lampiran 3) berbeda nyata $(\mathrm{P}<0,05)$ antara ayam broiler yang dipelihara pada suhu nyaman $\left(23-24^{\circ} \mathrm{C}\right)$ dan suhu pemeliharaan tinggi $\left(35-36^{\circ} \mathrm{C}\right)$. Rerata nilai drip loss (susut mentah) daging ayam broiler yang dipelihara pada suhu yang tinggi (35$36^{\circ} \mathrm{C}$ ) sebesar $4,18 \%$ sementara nilai drip pada pemeliharaan nyaman $\left(23-24^{\circ} \mathrm{C}\right)$ sebesar $2,62 \%$. Nilai drip loss daging broiler yang dipelihara pada suhu lingkungan tinggi $1,56 \%$ lebih tinggi daripada nilai drip daging yang dipelihara pada suhu nyaman. Presentase drip loss dari kedua perlakuan masih tergolong normal. Batas maksimum untuk drip loss dalam daging ayam segar yang diizinkan adalah $6,0 \%$ (Kato et al., 2013).

Drip loss (susut mentah) merupakan kehilangan berat daging selama 24 jam post mortem. Umumnya, drip loss adalah proses berkelanjutan yang melibatkan transfer air dari miofibril dalam jaringan otot ke ruang ekstraseluler (Yu et al., 2009). Perbedaan suhu pemeliharaan berpengaruh terhadap drip loss daging ayam broiler. Ayam pedaging dalam kelompok suhu tinggi memiliki drip loss daging yang lebih besar dibandingkan pada kelompok suhu nyaman, yang serupa dengan hasil Lu et al. (2017), yang menunjukkan kehilangan drip yang lebih besar pada daging dada broiler yang mengalami stres panas $\left(32^{\circ} \mathrm{C}\right)$. Perbedaan nilai drip loss tersebut dikaitkan dengan fungsi protein di otot setelah pemotongan. Ayam broiler yang dipelihara pada suhu 35$36^{\circ} \mathrm{C}$ akan mengalami stres panas sehingga mempercepat rigor mortis dan terjadi denaturasi protein. Denaturasi protein membuat protein daging memiliki kemampuan mengikat air yang rendah dan mengakibatkan struktur daging terbuka sehingga meningkatkan keluarnya drip pada daging. Hal ini sesuai dengan pendapat Sandercock et al. (2001) dalam Nkukwana et al. (2015), bahwa denaturasi protein myofibrilar dan sarcoplasmic dapat mengakibatkan fungsionalitasnya hilang sehingga kemampuan protein untuk mengikat air berkurang, menghasilkan water holding capacity yang buruk dan memfasilitasi hilangnya konstituen sarcoplasmic yang larut dari sel otot ke ruang ekstraseluler, akibatnya meningkatkan drip yang keluar dari daging. Santos et al. (2008) menemukan bahwa stres panas menyebabkan nilai WHC yang rendah karena hilangnya integritas membran akibat meningkatnya kreatin kinase dan jumlah hematokrit yang menurun. Sandercock et al. (2001) dalam Brossi et al. (2018), mengamati bahwa peningkatan aktivitas kreatin kinase menyebabkan nilai drip loss yang lebih tinggi pada dada ayam.

\section{Water Holding Capacity (WHC)}

Hasil analisis Water Holding Capacity (WHC) daging ayam broiler dengan perlakuan suhu pemeliharaan yang berbeda dapat dilihat pada tabel 3 dan perhitungan analisis ragam terdapat pada lampiran 4. Berdasarkan hasil uji t-test, Water Holding Capacity (WHC) daging ayam broiler pada kedua perlakuan adalah berbeda nyata $(\mathrm{P}<0,05)$. Rerata Water Holding Capacity (WHC) daging ayam broiler pada penelitian ini yaitu pada suhu pemeliharaan panas sebesar $21,59 \%$ dan suhu pemeliharaan nyaman sebesar $25,45 \%$. Nilai WHC pada suhu pemeliharaan nyaman tersebut masih tergolong baik, karena menurut Muchbianto (2009) dalam Pratama et al. (2015) nilai WHC normal daging ayam broiler segar berkisar antara 25-38\%. Namun, WHC daging ayam broiler yang dipelihara pada suhu lingkungan yang tinggi berada dibawah standar WHC daging. Hasil ini sesuai dengan penelitian hasil Santos et al. (2016), yang menunjukkan nilai water holding capacity yang lebih rendah pada daging dada broiler yang dipelihara pada kondisi stres panas $\left(32^{\circ} \mathrm{C}\right)$.

Water Holding Capacity (WHC) atau daya ikat air merupakan suatu parameter 
kualitas daging yang sangat penting terkait dengan seberapa besar kemampuan daging dalam mengikat air, oleh karena itu WHC yang tinggi mengidentifikasikan daging memiliki kualitas yang baik. Hasil penelitian ini menunjukkan bahwa perbedaan suhu pemeliharaan berpengaruh nyata terhadap WHC daging ayam broiler. Broiler yang dipelihara pada suhu $35-36{ }^{\circ} \mathrm{C}$ memiliki WHC yang lebih rendah. Perbedaan nilai WHC tersebut diduga akibat laju dan besarnya penurunan $\mathrm{pH}$ daging serta denaturasi protein daging. WHC daging broiler yang rendah tersebut diduga akibat broiler mengalami stres panas saat pemeliharaan pada suhu tinggi $\left(35-36^{\circ} \mathrm{C}\right)$ sehingga mengakibatkan denaturasi protein otot.

Denaturasi protein dapat mengurangi kemampuan protein otot dalam mengikat air dan menghasilkan kapasitas penahanan air yang buruk. Hal ini sesuai dengan Zhu et al. (2011), bahwa suhu tinggi dengan nilai $\mathrm{pH}$ rendah diketahui menyebabkan denaturasi protein sarkoplasma yang mengakibatkan koagulasi protein pada protein myofibrillar akan berpengaruh pada interaksi antara permukaan protein dan fase air di sekitarnya, sehingga mengurangi kapasitas menahan air. Wang et al. (2009) menambahkan bahwa stres panas mengakibatkan kemampuan mengikat air oleh protein rentan terhadap kerusakan oksidatif sehingga meningkatkan drip dan susut masak. Selain denaturasi protein otot, WHC juga dipengaruhi oleh nilai $\mathrm{pH}$ daging. WHC berkaitan dengan nilai $\mathrm{pH}$ daging, dimana daging dengan $\mathrm{pH}$ rendah maka nilai WHCnya juga rendah begitu pula sebaliknya. Hal ini sesuai dengan Öztürk and Serdarog־lu (2015), bahwa daging ayam dengan $\mathrm{pH}$ akhir rendah dan tingkat percepatan penurunan $\mathrm{pH}$ postmortem akibat akumulasi asam laktat dapat menyebabkan rusaknya protein miofibriler sehingga protein kehilangan kemampuan mengikat air dan memiliki kualitas water holding capacity daging yang buruk.

\section{Warna Daging}

Hasil analisis warna daging ayam broiler $\left(\mathrm{L}^{*}=\right.$ kecerahan, $\mathrm{a}^{*}=$ kemerahan dan $\mathrm{b}^{*}=$ kekuningan) dengan perlakuan suhu pemeliharaan yang berbeda dapat dilihat pada tabel 3. Nilai kecerahan, kemerahan dan kekuningan daging secara berurutan pada suhu pemeliharaan $35-36{ }^{\circ} \mathrm{C}$ yaitu $54,03 \pm 0,87 ; \quad 7,70 \pm 0,40 \quad$ dan $13,43 \pm 0,61$ sedangkan suhu pemeliharaan $23-24{ }^{\circ} \mathrm{C}$ yaitu $50,30 \pm 1,25 ; \quad 8,57 \pm 0,70$ dan $13,07 \pm 0,80$. Penelitian ini sejalan dengan penelitian Lu et al. (2017) yang melaporkan bahwa nilai $\mathrm{L}^{*}$ lebih tinggi untuk ayam pedaging yang dipelihara pada $32{ }^{\circ} \mathrm{C}$ daripada yang dipelihara pada $21^{\circ} \mathrm{C}$. Warna daging pada perlakuan suhu $35-36^{\circ} \mathrm{C}$ yaitu cenderung pucat karena nilai $\mathrm{L}^{*}$ yang tinggi dan termasuk kelainan warna daging yang biasa disebut pale, soft, exudative (PSE) sedangkan warna daging pada perlakuan suhu $23-24{ }^{\circ} \mathrm{C}$ tergolong normal. Menurut Qiao et al. (2001) dalam Downing et al. (2017) menyatakan bahwa daging dada ayam broiler yang memiliki nilai $\mathrm{L}^{*}$ lebih dari 53 dikategorikan daging PSE, jika nilai $\mathrm{L}^{*}$ adalah antara 48 dan 53 dianggap daging normal dan jika lebih rendah dari 46, itu bisa dianggap sebagai dark, firm, dry (DFD).

Warna daging merupakan salah satu kriteria kualitas penting yang terkait dengan $\mathrm{pH}$, daya ikat air, kekuatan geser daging yang menentukan kepuasan konsumen. Warna daging sebagai parameter penting untuk indikator daging PSE yang langsung dipengaruhi oleh denaturasi protein di otot dan $\mathrm{pH}$ postmortem (Barbut, 1997 dalam Öztürk dan Serdarog־lu, 2015). Hasil penelitian ini menunjukkan bahwa perbedaan kualitas fisik daging ayam yang dipelihara pada suhu panas $\left(35-36^{\circ} \mathrm{C}\right)$ dan suhu nyaman $\left(23-24^{\circ} \mathrm{C}\right)$ memberikan perbedaan yang berbeda nyata $(\mathrm{P}<0,05)$ atau adanya perbedaan terhadap kecerahan warna daging, warna kemerahan dan kekuningan daging, dimana ayam broiler yang dipelihara pada suhu $35-36{ }^{\circ} \mathrm{Cmemiliki}$ nilai kecerahan $\left(\mathrm{L}^{*}\right)$ yang lebih tinggi serta kemerahan $\left(\mathrm{a}^{*}\right)$ yang lebih rendah. Nilai $\mathrm{L}^{*}$ yang lebih tinggi pada ayam broiler yang mengalami stres panas 
sesuai dengan laporan Aksit et al. (2006), yang menunjukkan bahwa suhu pemeliharaan $34{ }^{\circ} \mathrm{C}$ meningkatkan kecerahan daging. Namun, nilai kekuningan $\left(b^{*}\right)$ dari daging dada ayam broiler menunjukkan tidak berbeda $(p>0,05)$. Menurut barbut (1997) dalam Tang et al. (2013) menyatakan bahwa observasi ini mungkin disebabkan oleh jenis otot karena nilai kecerahan $\left(\mathrm{L}^{*}\right)$ dan kemerahan $\left(a^{*}\right)$ lebih penting dan sensitif daripada nilai kekuningan $\left(b^{*}\right)$ pada otot putih.

Nilai kecerahan $\left(\mathrm{L}^{*}\right)$ yang lebih tinggi pada pemeliharaan dengan suhu tinggi diduga karena stres panas pada broiler sebelum pemotongan menyebabkan tingginya asam laktat pada daging ayam broiler postmortem sehingga terjadi penurunan $\mathrm{pH}$ secara cepat yang menghasilkan $\mathrm{pH}$ yang rendah dan denaturasi protein menyebabkan warna permukaan daging yang lebih pucat. Tingkat percepatan glikolisis postmortem mengubah warna otot. Hal ini sesuai dengan pendapat Kanani et al. (2017), bahwa stres panas merangsang proses glikolisis dan akibatnya penurunan $\mathrm{pH}$ yang cepat dan fenomena ini menyebabkan daging pucat (PSE) serta menurunkan warna kemerahan daging dada broiler. Warna daging berkorelasi dengan $\mathrm{pH}$ daging postmortem. $\mathrm{pH}$ yang rendah akan menghasilkan warna daging yang pucat dan $\mathrm{pH}$ yang lebih tinggi memberikan warna daging yang lebih gelap. Sebagaimana yang dijelaskan Karunanayaka et al. (2016), bahwa warna pucat pada daging karena $\mathrm{pH}$ yang rendah yang terjadi akibat denaturasi protein myofibrilar dan sarcoplasmic. Adams dan Moss (2000) dalam King dan Whyte (2006), menambahkan bahwa pH daging yang rendah cenderung meningkatkan oksidasi oksiminoglobin (oxyMb) dan deoxymyoglobin (deoxyMb) ke metimoglobin (metMb) coklat, yang dikombinasikan dengan tingginya hamburan cahaya dari permukaan daging, sehingga memberikan warna pucat pada daging. Langer et al. (2010) menyatakan bahwa tingkat perubahan warna terkait erat dengan laju oksidasi mioglobin yang disebabkan oleh oksidasi lipid, yang mana keterkaitan antara warna daging pucat dengan denaturasi protein sarkoplasma menyebabkan peningkatan hamburan cahaya di otot. Menurut Dadgar et al. (2010), bahwa stres panas sebelum pemotongan dapat menyebabkan penurunan konsentrasi pigmen total, dimana konsentrasi pigmen yang lebih rendah dapat dikaitkan dengan laju cepat glikolisis postmortem pada suhu tinggi yang menghasilkan penurunan $\mathrm{pH}$ yang cepat dan penurunan intensitas warna dan denaturasi mioglobin.

Warna kemerahan (a*) daging berkorelasi dengan warna kecerahan daging (L*). Menurut Dadgar et al. (2010), bahwa kecenderungan daging dada menunjukkan nilai $a^{*}$ yang lebih tinggi (lebih merah) ketika nilai $\mathrm{L}^{*}$ menurun (menjadi lebih gelap). Zhang et al. (2012) menyatakan bahwa ayam broiler yang terkena stres panas memiliki hasil penurunan nilai kemerahan (a*) karena ada lebih banyak mioglobin teroksidasi dalam ototnya. Tang et al. (2013) menambahkan bahwa nilai kemerahan daging yang rendah tergantung pada nilai $\mathrm{pH}$ rendah secara konsisten, yang berkontribusi pada reaksi redoks yang tidak biasa dari mioglobin dan hemoglobin. Penentuan warna merah pada daging dipengaruhi oleh banyak faktor yaitu jumlah myoglobin, hemoglobin, dan pigmen heme yang menentukan tingkat kemerahan daging (Ngoka dan Froning, 1982 dalam Wideman et al., 2016). Warna kuning daging berasal dari pigmen dalam pakan. Menurut Fletcher (2002) dalam Garcia et al. (2010), bahwa pigmen kuning pada daging unggas dipengaruhi oleh faktorfaktor seperti keturunan genetik pada unggas, pigmen bahan pakan (carotenoid), kesehatan burung, dan pengolahan daging.

\section{KESIMPULAN}

Simpulan dari penelitian ini adalah ayam broiler yang dipelihara pada suhu lingkungan tinggi $\left(35-36^{\circ} \mathrm{C}\right)$ memiliki kualitas fisik daging yang lebih rendah dibandingkan dengan yang dipelihara pada suhu nyaman $\left(23-24^{\circ} \mathrm{C}\right)$. 
Saran

Kajian yang lebih lanjut diperlukan untuk sepenuhnya menjelaskan efek stres panas pada pemeliharaan ayam broiler terhadap kualitas fisik daging khususnya warna daging, terutama pada waktu yang berbeda dari paparan serta temperatur pemeliharaan yang berbeda.

\section{DAFTAR PUSTAKA}

Aksit, M., S. Yalcın, S. Ozkan, K. Metin and D. Ozdemir. 2006. Effects of temperature during rearing and crating on stress parameters and meat quality of broilers. Journal Poultry Sci. 85:1867-1874.

BPS. 2017. Statistik Indonesia 2017. Katalog BPS: 1101001. Badan Pusat Statistik. Jakarta.http://www.bps.go.id/index.php / publikasi/326. 22 Juni 2017.

Brossi, C., N. Montes-Villanueva, J.D. RiosMera, E.F. Delgado, J.M. Menten, C.J. Contreras-Castillo. 2018. Acute heat stress detrimental effects transpose high mortality rate and affecting broiler breast meat quality. Journal Scientia Agropecuaria. 9 (3): 305-311.

Dadgar, S., E.S. Lee, T.L.V. Leer, N. Burlinguette, H.L. Classen, T.G. Crowe dan P.J. Shand. 2010. Effect of microclimate temperature during transportation of broiler chickens on quality of the pectoralis major muscle. Jornal Poultry Sci. 89 :1033-1041.

Downing, J.A., M.J. Kerr dan D.L. Hopkins. 2017. The effects of pre-transport supplementation with electrolytes and betaine on performance, carcass yield and meat quality of broilers in summer and winter. Journal Livestock Sci. 205: 16-23.

Kanani, P.B., M. Daneshyar, J. Aliakbarlu dan F. Hamian. 2017. Effect of dietary turmeric and cinnamon powders on meat quality and lipid peroxidation of broiler chicken under heat stress condition. Journal Veterinary Research Forum. 8 (2): 163169.
Kato, T., C.F. Barbosa, E.I. Ida, A.L. Soares, M. Shimokomaki dan M. R. Pedrao. 2013. Broiler chicken PSE (pale, soft, exudative) meat and water release during chicken carcass thawing and Brazilian Legislation. Brazilian. Arch. Biol. Technol, 56 (6): 996-1001.

King, N.J. dan R. Whyte. 2006. Factors That Influence Cooked Meat Color. Journal Food Sci. 71 (4): 31-40.

Kusnadi, E. 2009. Perubahan malonaldehida hati, bobot relatif bursa fabricius dan rasio heterofi 1/limfosit $(\mathrm{h} / \mathrm{l})$ ayam broiler yang diberi cekaman panas. Jurnal Media Peternakan. 32 (2): 81 87.

Langer, R.O.S., G.S. Simões, A.L. Soares, A. Oba, A. Rossa, M. Shimokomaki dan E.I. Ida. 2010. Broiler transportation conditions in a Brazilian commercial line and the occurrence of breast PSE (pale, soft, exudative) meat and DFDlike (dark, firm, dry) meat. Brazilian. Arch. Biol. Technol. 53 (5): 11611167.

Lee, N., V. Sharma, N. Brown dan A. Mohan. 2015. Functional properties of bicarbonates and lactic acid on chicken breast retail display properties and cooked meat quality. Journal Poultry Sci. 94: 302-310.

Lu, Z., X. He,B. Ma,L. Zhang,J. Li,Y. Jiang, G. Zhou dan F. Gao. 2017. Chronic heat stress impairs the quality of breast-muscle meat in broilers by affecting redox status and energy-substance metabolism. Journal Agriculture Food Chemical, 65 (51): 11251-11258.

Nkukwana, T.T., V. Muchenje, P.J. Masika, E. Pieterse, L.C. Hoffman dan K. Dzama. 2015. Proximate composition and variation in colour, drip loss and $\mathrm{pH}$ of breast meat from broilers supplemented with Moringa oleifera leaf meal over time. Animal Production Sci. 56: 1208-1216.

Öztürk, B. dan M. Serdarog־lu. 2015. Quality characteristics of PSE-like Turkey 
pectoralis major muscles generated by high post-mortem temperature in a Local Turkish slaughterhouse. Korean Journal Food Science Animal. 35 (4): 524-532.

Pratama, A., K. Suradi, R.L. Balia, H. Chairunnisa, H. AW Lengkey, D.S. Sutardjo, L. Suryaningsih, J. Gumilar, E. Wulandari dan W.S. Putranto. 2015. Evaluasi karakteristik sifat fisik karkas ayam broiler berdasarkan bobot badan hidup. Jurnal Ilmu Ternak, 15 (2): 61-64.

Santos, C.C., E.F. Delgado, J.F.M. Menten, A.C.M. Pedreira, C.J.C. Castillo, G.B. Mourão, C. Brossi, I.J. O. da Silva. 2008. Sarcoplasmatic and myofibrillar protein changes caused by acute heat stress in broiler chicken. Sciece Agriculture. 65 (5): 453-458.

Santos, V.A.B., A.G. Ganecco, J. Lolli, M.P. Berton, R.D. Cássia, G. Mitzi BM, M.M. Boiago, L. Miyagusku, H. Borba dan P.A. de Souza. 2016. Broiler meat quality evaluation created in simulated conditions of heat. Journal Food Process Technology, 7 (11): 1-9.

Setiaji, D dan A. Sudarman. 2006. Ekstrak daun beluntas (Pluchea indica less.) sebagai obat antistres pada ayam broiler. Jurnal Media Peternakan. 28 (2): 45-51.

Song, D.J. dan A.J. King. 2015. Effects of heat stress on broiler meat quality. World's Poult. Science Journal, 71: 701-709.

Sugito, Fakhrurrazi dan M. Isa. 2011. Efek pemberian ekstrak Jaloh dikombinasi dengan probiotik dan kromium terhadap profil hematologi dan titer antibodi vaksin ND pada ayam broiler yang mengalami stres panas. Jurnal Agripet. 11(2): 8 - 15 .

Tang, S., J. Yu, M. Zhang dan E. Bao. 2013. Effects of different heat stress periods on various blood and meat quality parameters in young Arbor Acer broiler chickens. Canadian Journal Animal Science. $93:$ 453-460.

Toplu, H.D.G., A. Nazligül, S. Karaarslan, M. Kaya dan O. Yagin. 2014. Effects of heat conditioning and dietary ascorbic acid supplementation on growth performance, carcass and meat quality characteristics in heat-stressed broilers. Ankara Üniv Vet Fak Derg, 61: 295-302.

Wang, R.R., Pan, X.J. dan Z.Q Peng. (2009) Effects of heat exposure on muscle oxidation and protein functionalities of pectoralis majors in broiler. Journal Poultri Sci. 88: 1078-1084.

Wang, R.H., R. R. Liang, H. Lin, L.X. Zhu, Y.M. Zhang, Y.W. Mao, P.C Dong, L.B. Niu, M.H. Zhang and X. Luo. 2017. Effect of acute heat stress and slaughter processing on poultry meat quality and postmortem carbohydrate metabolism. Poultry Sci. 96 (3): 738746.

Yu, L.H., E.S. Lee, J.Y. Jeong, J.H. Choi dan C.J. Kim. 2009. Effects of post-mortem temperature on the physicochemical properties of hot-boned chicken breast muscles. Korean Journal Food Science Animal Resource. 29 (1): 55-61.

Zhang, Z. Y., G. Q. Jia, J. J. Zuo, Y. Zhang, J. Lei, L. Ren dan D.Y. Feng. 2012. Effects of constant and cyclic heat stress on muscle metabolism and meat quality of broiler breast fillet and thigh meat. Journal Poultry Sci. 91 :29312937.

Zhu, X., M. Ruusunen, M. Gusella, M. YläAjos, X. Xu, G. Zhou and E. Puolanne. 2013. High early post-mortem temperature induces activation of AMP-activated protein kinase and development of pale, soft and exudative characteristics in turkey muscles. Meat Science, 93: 600-606 